\title{
THE EFFECT OF ALLOYING METHOD ON THE STRUCTURE AND PROPERTIES OF SINTERED STAINLESS STEEL
}

Sintered duplex stainless steels (SDSSs) appear to be very interesting and promising materials that can be used in many industrial sectors. Ferrite improves material strength while austenite increases hardness and corrosion resistance. This study proposes a method to improve functional properties (e.g. hardness and wear resistance) by means of alloying the surface of the sintered duplex steel with $\mathrm{Cr}_{3} \mathrm{C}_{2}+10 \% \mathrm{NiAl}$ powder. The results of optical microscope metallography, SEM/EDX, XRD analysis and microhardness and wear resistance measurements are also presented. The surface alloying with $\mathrm{Cr}_{3} \mathrm{C}_{2}$ is a manufacturing method of surface layer hardening in sintered stainless steels and modification of surface layer properties such as hardness and coefficient of friction.

Keywords: sintered duplex stainless steel, chromium carbide

\section{Introduction}

Powder metallurgy of stainless steel constituents represents a dynamically growing area of PM applications, of which sintered stainless steel cover a variety of industries, including aerospace, automotive, chemical processing and medical sectors [1-5]. Proper processing and sintering of sintered stainless steel are an extremely important factor in achieving good properties for exacting applications. Selection of an alloy for a specific application depends on a number of factors, with the most important criterion usually being corrosion resistance. Furthermore, other criteria that are taken into account during alloy selection are mechanical properties, thermal and magnetic properties, resistance to oxidation and creep, and costs [1,6].Nowadays, a very interesting and promising material is sintered duplex stainless steels (SDSSs). They are characterized by a two-phase structure consisting of approximately equal content of ferrite and austenite [7-8]. Compared to austenitic grades, ferritic stainless steels are less corrosion resistant, are characterized by lower rate of work hardening, improved machinability, good formability and ductility, and their advanced temperature strength is lower. Austenitic stainless steels offer improved corrosion resistance and they are preferred for applications exposed to elevated temperatures. Consequently, two materials with different properties can coexist. Furthermore, sintered duplex stainless steel manufactured using the PM technology are a perfect alternative to steels obtained using the conventional methods and are attracting much attention, especially in highly industrialized countries [9-11].
Limitations to application of sintered duplex steels result from both anticorrosion properties and reduced wear resistance. Modification of surface properties of engineering materials, especially stainless steels, is intended to improve function and usability these materials. The choice of a surface material with adequate thermal properties and wear resistance and corrosion has a decisive effect on functionality [12-13]. The adequate properties of surface-engineered parts include increased corrosion resistance, wear resistance and mechanical properties, such as fatigue resistance and toughness [14-17].

Analysis of the literature leads to the conclusion that surface processing of sintered duplex steels represents an extremely rear object of research, both in Poland and abroad. Few studies that have focused on these problems have been mainly based on the use of laser as a concentrated source of energy for remelting of the surface layer of sintered steels [7,18-19].

Therefore, the purpose of this paper was to evaluate the effect of surface alloying with $\mathrm{Cr}_{3} \mathrm{C}_{2}+10 \% \mathrm{NiAl}$ powder on the structure and properties of the sintered stainless steel. The coating with thickness of $60 \mu \mathrm{m}$ was deposited on the steel surface using the plasma spraying method. The GTAW (TIG) method was used to remelt the coating with the steel base material and the effect of atmospheric plasma spraying and surface alloying with $\mathrm{Cr}_{3} \mathrm{C}_{2}$ on the microstructure and functional properties of sintered duplex stainless steel was evaluated. The benefits of using the GTAW (Gas Tungsten Arc Welding) methodology for surface processing of materials have been documented in numerous studies published by the research team [7].

\footnotetext{
CZESTOCHOWA UNIVERSITY OF TECHNOLOGY, FACULTY OF PROCESSING ENGINEERING AND MATERIALS TECHNOLOGY, INSTITUTE FOR MATERIAL ENGINEERING, 19 ARMII KRAJOWEJ AV.,42-200 CZĘSTOCHOWA, POLAND.

** CZESTOCHOWA UNIVERSITY OF TECHNOLOGY, FACULTY OF MANAGEMENT, DEPARTMENT OF PRODUCTION ENGINEERING, 19 ARMII KRAJOWEJ AV.,42-200 CZĘSTOCHOWA, POLAND

\# Corresponding author: dudek@wip.pcz.pl
} 


\section{Material and methods}

The specimens for the examinations were obtained from water-atomized powders of 316L steel and ferritic 409L steel manufactured by Höganäs (Sweden). Chemical composition of steel powders was presented in Table 1. Both powders selected nominal particle size of $150 \mu \mathrm{m}$.

TABLE 1

Chemical composition of steel powders (\%wt.)

\begin{tabular}{|c|c|c|c|c|c|c|c|c|}
\hline \hline $\begin{array}{c}\text { Powder } \\
\text { grade }\end{array}$ & $\mathbf{C r}$ & $\mathbf{N i}$ & $\mathbf{M o}$ & $\mathbf{S i}$ & $\mathbf{M n}$ & $\mathbf{C}$ & $\mathbf{S}$ & $\mathbf{F e}$ \\
\hline 316L & 16.8 & 12.0 & 2.0 & 0.9 & 0.1 & 0.022 & 0.005 & Balance \\
\hline 409L & 11.86 & 0.14 & 0.02 & 0.82 & 0.14 & 0.02 & 0.01 & Balance \\
\hline
\end{tabular}

Powders were mixed with 50:50 ratio with addition of $1 \%$ of Acrawax C lubricant and compacted uniaxially at $720 \mathrm{MPa}$. The moulded pieces were sintered at the temperature of $1250^{\circ} \mathrm{C}$ for 30 minutes in the dissociated hydrogen medium and cooled down with cooling rate of $0.5^{\circ} \mathrm{C} / \mathrm{s}$.

Furthermore, in order to improve functional properties of SDSSs, a modified layer was suggested to be formed using the following stages:

- application of the $\mathrm{Cr}_{3} \mathrm{C}_{2}+10 \% \mathrm{NiAl}$ coating on sintered stainless steel base material by means of plasma spraying (APS method),

- alloying of the coatings (using GTAW technology) at different current and voltage parameters in order to melt the coating with base material.

The quantitative test of $\mathrm{Cr}_{3} \mathrm{C}_{2}$ powder shape was performed using the Image-Pro Plus software. Table 2 shows parameters used in the test. Micrographs were processed to highlight grain boundaries. Furthermore, calibration was carried out to receive results in length units $(\mu \mathrm{m})$.

TABLE 2

Image-Pro Plus parameters

\begin{tabular}{|c|l|}
\hline \hline Parameters & \multicolumn{1}{|c|}{ Specification } \\
\hline Area & The surface grains will be defined \\
\hline Angle & $\begin{array}{l}\text { The angle between the major axis and the vertical } \\
\text { will be defined }\end{array}$ \\
\hline Diameter & $\begin{array}{l}\text { Specified as the average length of diameters } \\
\text { measured at 2 degree intervals and passing through } \\
\text { object centroid }\end{array}$ \\
\hline
\end{tabular}

The alloying treatment of sintered steel was performed by means of GTAW arc method with constant surface scanning rate of $340 \mathrm{~mm} / \mathrm{min}$ and changing welding current intensity, with its values ranging from 20 to $50 \mathrm{~A}$. The shielding gas was argon, with the flow set at $\sim 14 \mathrm{l} / \mathrm{min}$.

Analysis of microstructure after application of $\mathrm{Cr}_{3} \mathrm{C}_{2}$ powder and surface alloying was carried out using the stereo microscope, optical microscope Axiovert 25 and scanning microscope Jeol JSM 5400. The Vickers method (with the load of
$980.7 \mathrm{mN}$ ) was employed to measure microhardness of sintered steel, coating and remelted surface layers.

Identification of phase composition was carried out using the X-ray diffractometer (Seifert $3003 \mathrm{~T}-\mathrm{T}$ ) with a cobalt lamp with characteristic radiation wavelength of $\lambda_{\operatorname{cok} \alpha}=0.17902 \mathrm{~nm}$. Other parameters are presented in Table 3.

TABLE 3

X-ray diffractometer parameters

\begin{tabular}{|l|c|}
\hline \multicolumn{1}{|c|}{ Parameters } & Ranges \\
\hline Supply voltage $\left(\boldsymbol{U}_{\boldsymbol{r}}\right)$ & $30 \div 40[\mathrm{kV}]$ \\
\hline Current intensity $\left(\boldsymbol{I}_{\boldsymbol{r}}\right)$ & $30 \div 40[\mathrm{~mA}]$ \\
\hline Angle range (20) & $10 \div 120^{\circ}$ \\
\hline Measurement step & $0.1^{\circ}$ \\
\hline Pulse integration time $\left(\boldsymbol{t}_{\boldsymbol{r}}\right)$ & $10[\mathrm{~s}]$ \\
\hline
\end{tabular}

The Hommel T1000 contact profilometer was used to determine parameters that characterized surface topography ( $R a$, $R q, R p, R v k, R t, R \max )$ for each sample. The measurements were repeated three times in contact with the surface examined through coupling of the stylus with a differential measurement system.

The scratch resistance test (Revetest XPress Plus using Rockwell indented tip) was performed in order to determine coefficient of friction for sintered duplex stainless steel obtained in the study. The following parameters were maintained during the test: permanent load of $10 \mathrm{~N}$, scratch length $5 \mathrm{~mm}$, scratch rate $5 \mathrm{~mm} / \mathrm{min}$.

\section{Results and discussion}

Figure 1 presents photographs of grains of $\mathrm{Cr}_{3} \mathrm{C}_{2}$ powder obtained by the scanning microscope Jeol JSM 5400.

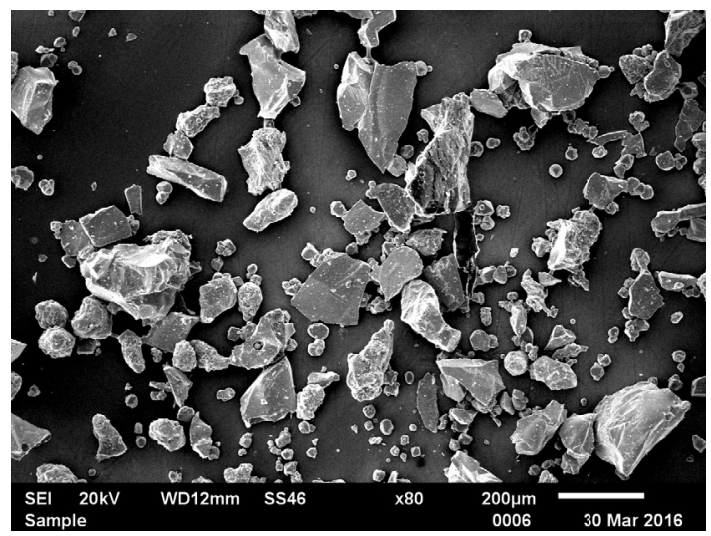

Fig. 1. Grains of $\mathrm{Cr}_{3} \mathrm{C}_{2}$ powder

Results of stereological analysis of the powder used are presented in Figure 2. Analysis concerned diameter, area and angle for powder grains, which were characterized by polyhedral shapes.

$\mathrm{Cr}_{3} \mathrm{C}_{2}$ grains were not spatially oriented, whereas the range of angles between major axis and the vertical axis was $19 \div 175^{\circ}$. 

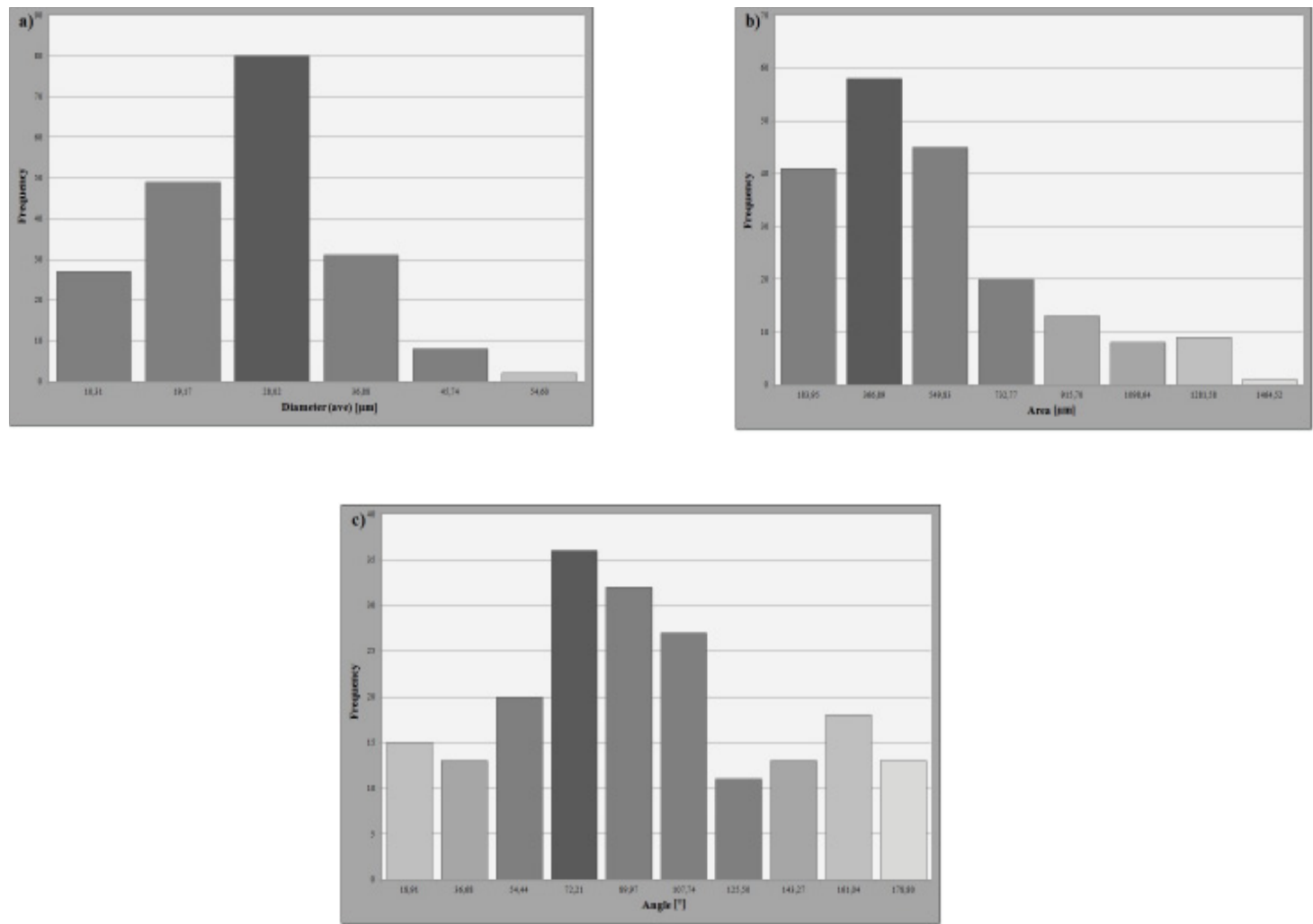

Fig. 2. Histograms for $\mathrm{Cr}_{3} \mathrm{C}_{2}$ : a) diameter, b) area, c) angle

Parameters such as the diameter, area and angle showed approximately the Gaussian distribution. The diameter ranged from $1.45 \mu \mathrm{m}$ to $54.60 \mu \mathrm{m}$, with the mean sample size of $28.02 \mu \mathrm{m}$. Mean surface for the powder studied was ca. $360 \mu \mathrm{m}$.

Microstructures of the SDSSs are shown in Figure 3.

Micrographs showed a clear separation of austenitic (brighter grain) and ferritic (darker grains) phases.

The coating obtained using plasma spraying on the SDSS surface had thickness of ca. $60 \mu \mathrm{m}$. Figure 4 presents the microstructures of the coating surface (before alloying process) obtained from a stereo microscope (Fig. 4a) and the Jeol JSM 5400 scanning microscope (Fig. 4b). Figure 5 presents the crosssection of microstructure obtained by the Axiovert 25 optical microscope.
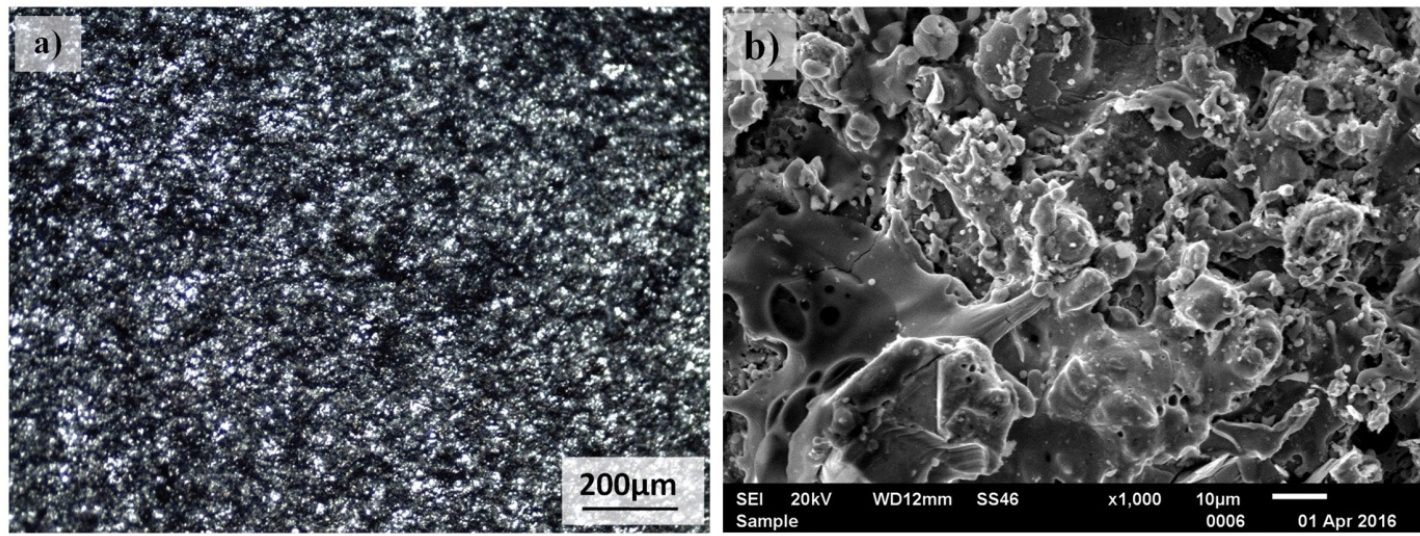

Fig. 4. Microstructure of sintered duplex stainless steel: a,b) coating after APS 


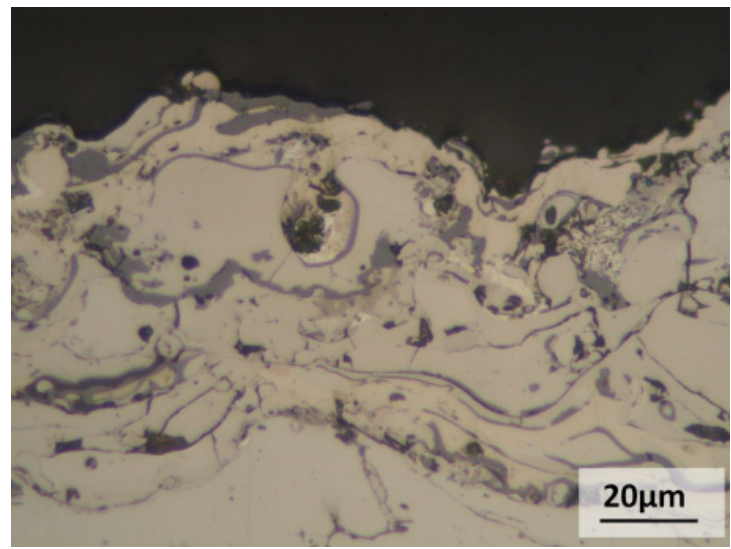

Fig. 5. Cross-section of coating microstructure obtained by the optical microscope Axiovert 25

The coatings obtained in the study show elements of structure typical of this method of deposition - porosity, layers, heterogeneity. They have typical porous lamellar structure with cracks and non-melted particles.

Macroscopic examinations were used to evaluate the effect of alloying on surface quality. Welding current intensity of up to $30 \mathrm{~A}$ was too low to initiate remelting of the surface. Using such criteria as good surface quality (lack of welding defects) and measurability of the width and depth of the fusion, further studies were carried out based on the sinters remelted at current intensities of 40A and higher. Positive macroscopic results were obtained for the bands remelted at 50A, which were characterized by smooth surface without defects (i.e. craters, cracks).

Figure 6 presents the microstructure of the surface after alloying process obtained by the scanning microscope Jeol JSM 5400.

The microstructures were observed using the metallographic sections etched with aqua regia. Figure 7 presents the microstructure obtained for sintered duplex stainless steel after surface alloying treatment (Axiovert 25 optical microscope).
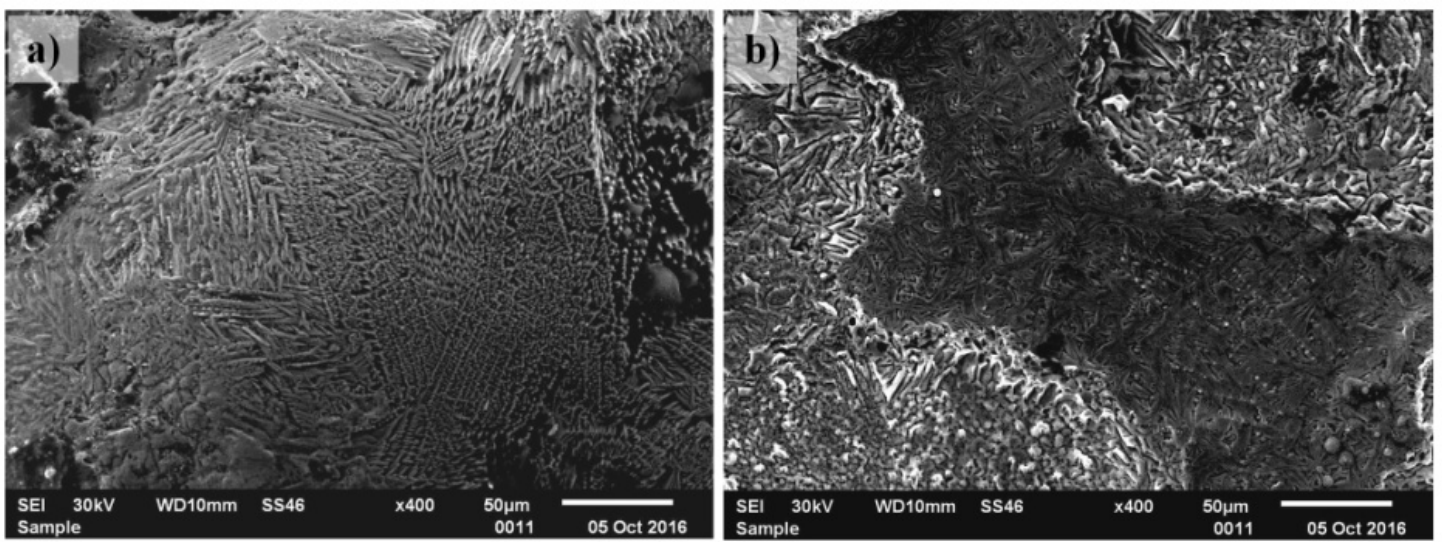

Fig. 6. Microstructure of the surface of sintered duplex stainless steel: a) after alloying at current intensity of 40A, b) after alloying at current intensity of $50 \mathrm{~A}$

Microscopic examinations revealed uniform microstructure in the surface layers after arc remelting (alloying). The treatment was accompanied by the fast heat transfer and high gradient of temperature, which resulted in the formation of the primary structure with columnar crystals oriented according to the direction of heat transfer. A cellular-dendritic structure was formed in the microstructure of surface after alloying process. Microscopic examinations showed also epitaxial character of nucleation and growth of primary structure cells, initiated in the transition zone formed as a result of base material remelting.

Results of the analysis of phase composition of the sintered duplex stainless steel with $\mathrm{Cr}_{3} \mathrm{C}_{2}$ are presented in Figure 8 .

Analysis of phase composition revealed presence of the $\mathrm{Cr}_{3} \mathrm{C}_{2}$ phase which crystallizes in the orthorhombic cell (cell parameters: $a=0.55 \mathrm{~nm}, b=1.14 \mathrm{~nm}, c=0.28 \mathrm{~nm}, \alpha=\beta=\gamma=90^{\circ}$ ) and peaks from NiAl that crystallizes in the cubic cell of $\mathrm{Pm} 3 \mathrm{~m}$ (cell parameters: $a=b=c=0.28 \mathrm{~nm}, \alpha=\beta=\gamma=90^{\circ}$ ). Alloying of the sintered steel resulted in the reduction in the percentage of the $\mathrm{Cr}_{3} \mathrm{C}_{2}$ phase and solving of $\mathrm{Cr}$ in the crystallographic
$\mathrm{Fe} \alpha$, which is noticeable in the diffractogram through changes in the values of the parameter $d_{h k l}$ and the parameter of lattice constant for $\mathrm{A} 2-\mathrm{Fe} \alpha$.

Analysis of geometric structure was based on the profile method and results of roughness parameters. Table 4 and Figure 9 present the results of examinations of the $\mathrm{Cr}_{3} \mathrm{C}_{2}$ coating and for the surface sintered duplex stainless steel and after alloying at current intensity of $35 \mathrm{~A}, 40 \mathrm{~A}$ and $50 \mathrm{~A}$.

TABLE 4

Surface roughness of sintered steels in the initial state (coating) and layer after alloying

\begin{tabular}{|c|c|c|c|c|c|c|c|}
\hline \multirow{2}{*}{\multicolumn{2}{|c|}{ Surface condition }} & \multicolumn{6}{|c|}{ Roughness parameter $(\mu \mathrm{m})$} \\
\hline & & $R a$ & $R q$ & $R p$ & $R v k$ & $R t$ & $R \max$ \\
\hline \multicolumn{2}{|l|}{ Coating } & 8.85 & 11.89 & 43.62 & 13.41 & 72.13 & 68.73 \\
\hline \multirow{3}{*}{$\begin{array}{l}\text { Surface after } \\
\text { alloying } \\
\text { at current } \\
\text { intensity }\end{array}$} & 35A & 7.97 & 9.51 & 22.60 & 7.32 & 47.12 & 47.12 \\
\hline & $40 \mathrm{~A}$ & 7.67 & 9.62 & 25.11 & 11.68 & 51.70 & 50.84 \\
\hline & 50A & 6.82 & 8.93 & 29.20 & 12.79 & 53.88 & 47.92 \\
\hline
\end{tabular}



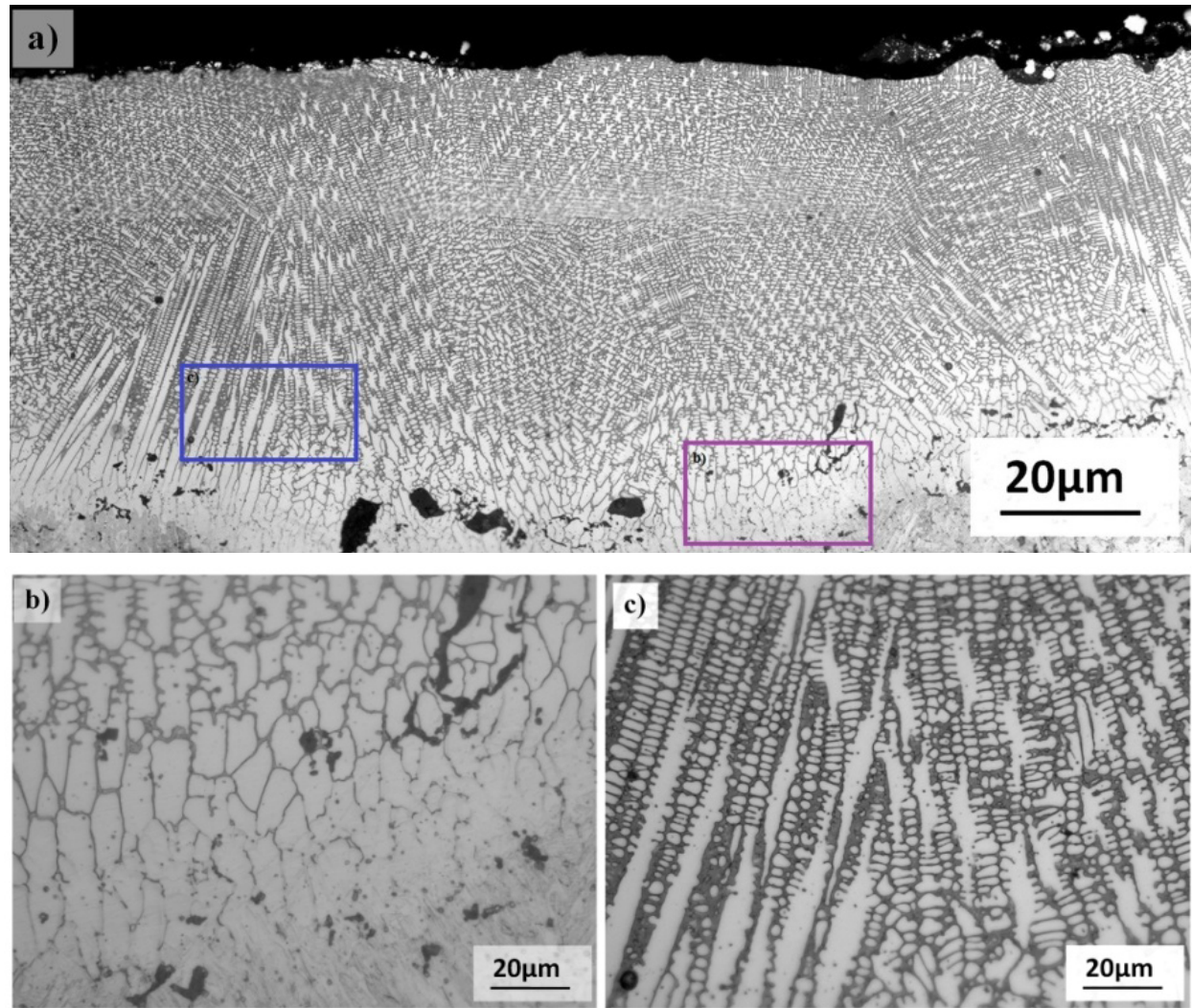

Fig. 7. Microstructure of the alloyed layer for remelting with current intensity of $50 \mathrm{~A}$, (a) structure of the entire alloyed zone, (b) boundary of the alloying zone and heat affected zone, (c) upper part of the alloyed zone

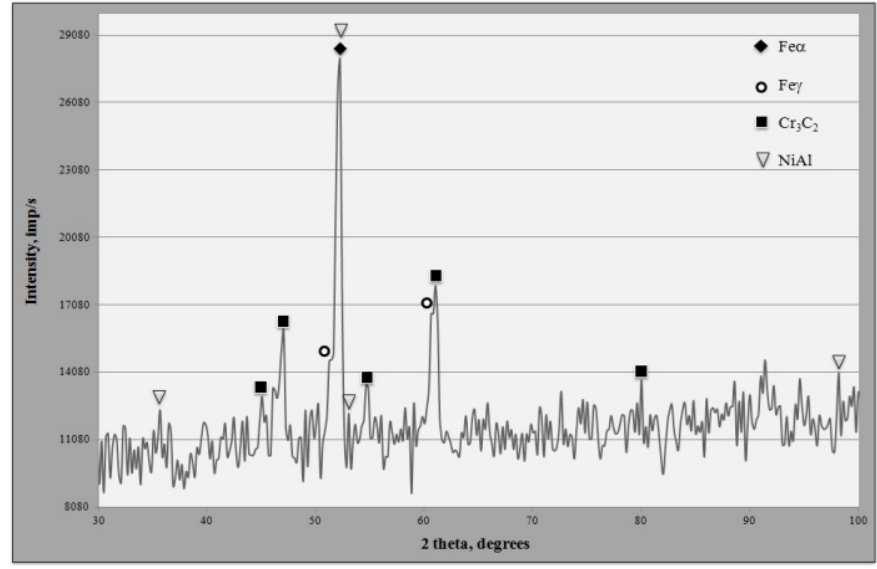

Fig. 8. Diffractogram of the $\mathrm{Cr}_{3} \mathrm{C}_{2}$ coating on the sintered duplex stainless steel

In the initial state (coating after ASP), the surface of the sinters was characterized by roughness of $R a=8.85 \mu \mathrm{m}$. Alloying using GTAW method caused an insignificant reduction in surface roughness, which is demonstrated by lower values of e.g. $R a, R q$ and $R$ max parameters compared to the initial state. The lower values of the $R a$ parameter were observed in all the alloyed zones compared to the surface of the coating.

Figure 10 presents example SEM microstructure images and EDS spectra in alloyed zones with EDX analysis areas. Table 5 presents analysis of chemical composition of the surface layers in duplex stainless steel after alloying.
TABLE 5

EDX-analysis of chemical composition of the surface in sintered duplex stainless steels after alloying at current intensity of $40 \mathrm{~A}$ and $50 \mathrm{~A}$

(location of the measurements is marked in Fig. 10)

\begin{tabular}{|c|c|c|c|}
\hline \hline Intensity & Element & $\begin{array}{c}\text { Spectrum 1 } \\
\text { (weight \%) }\end{array}$ & $\begin{array}{c}\text { Spectrum 2 } \\
\text { (weight \%) }\end{array}$ \\
\hline \multirow{4}{*}{ 40A } & $\mathbf{C}$ & 16.61 & 18.99 \\
\cline { 2 - 4 } & $\mathbf{A l}$ & 0.72 & 1.96 \\
\cline { 2 - 4 } & $\mathbf{S i}$ & 0.25 & 0.36 \\
\cline { 2 - 4 } & $\mathbf{C r}$ & 40.98 & 42.03 \\
\cline { 2 - 4 } & $\mathbf{F e}$ & 9.35 & 1.11 \\
\cline { 2 - 4 } & $\mathbf{N i}$ & 32.10 & 25.96 \\
\cline { 2 - 4 } & $\mathbf{O}$ & & 9.59 \\
\hline \multirow{5}{*}{$\mathbf{5 0 A}$} & $\mathbf{C}$ & 7.13 & 12.08 \\
\cline { 2 - 4 } & $\mathbf{A l}$ & - & 15.17 \\
\cline { 2 - 4 } & $\mathbf{S i}$ & 0.63 & 0.38 \\
\cline { 2 - 4 } & $\mathbf{C r}$ & 27.15 & 28.32 \\
\cline { 2 - 4 } & $\mathbf{F e}$ & 50.89 & 1.96 \\
\cline { 2 - 4 } & $\mathbf{N i}$ & 13.10 & 23.87 \\
\cline { 2 - 4 } & $\mathbf{O}$ & - & 18.22 \\
\cline { 2 - 4 } & $\mathbf{M o}$ & 1.09 & - \\
\hline
\end{tabular}

Examinations of the chemical composition of the alloyed layer demonstrate that the increase in current and voltage parameters causes an increase in the content of the elements present in the base material, such as $\mathrm{Fe}, \mathrm{Mo}, \mathrm{Si}$, which suggests intensification of the processes of mixing the coating with the material of the duplex steel. The remelting pathway for all the 

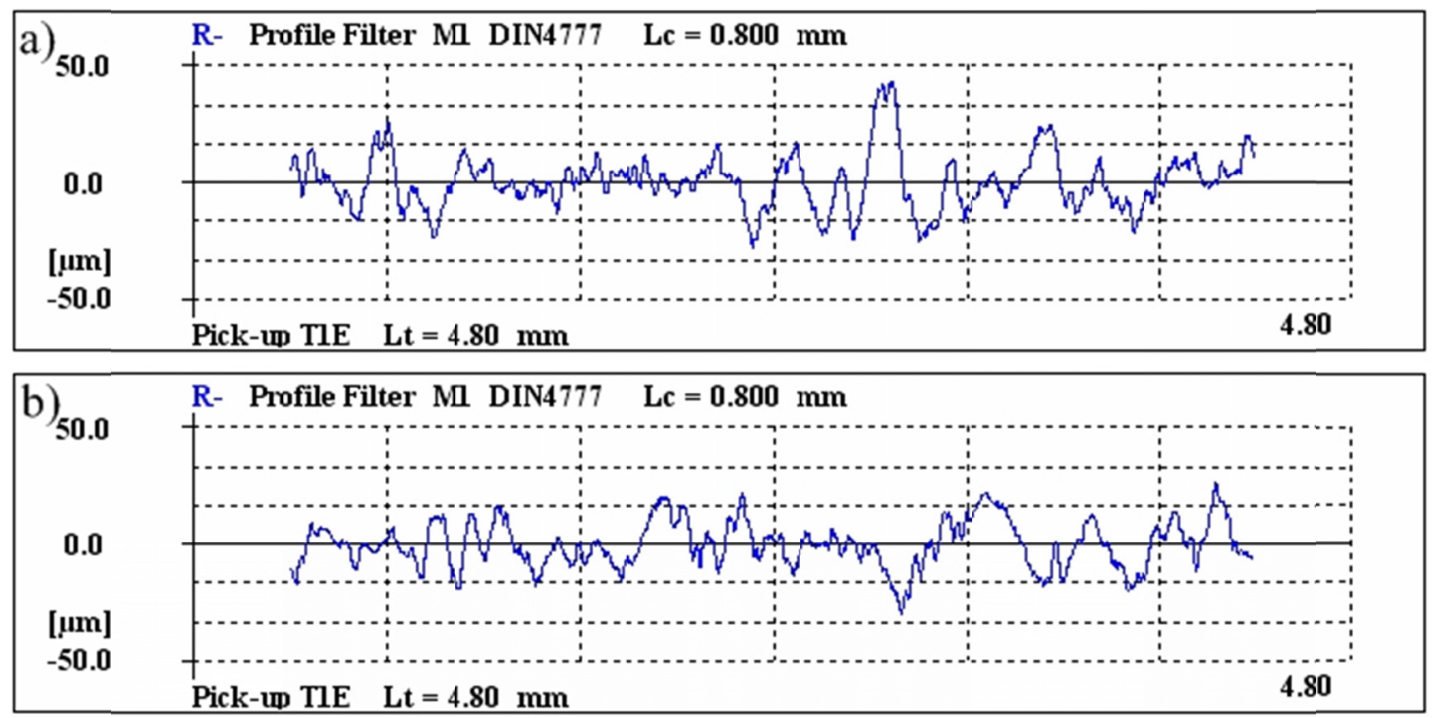

Fig. 9. Diagram of profilograph for sintered duplex stainless steel: a) $\mathrm{Cr}_{3} \mathrm{C}_{2}$ coating, b) after alloying at current intensity of 35A
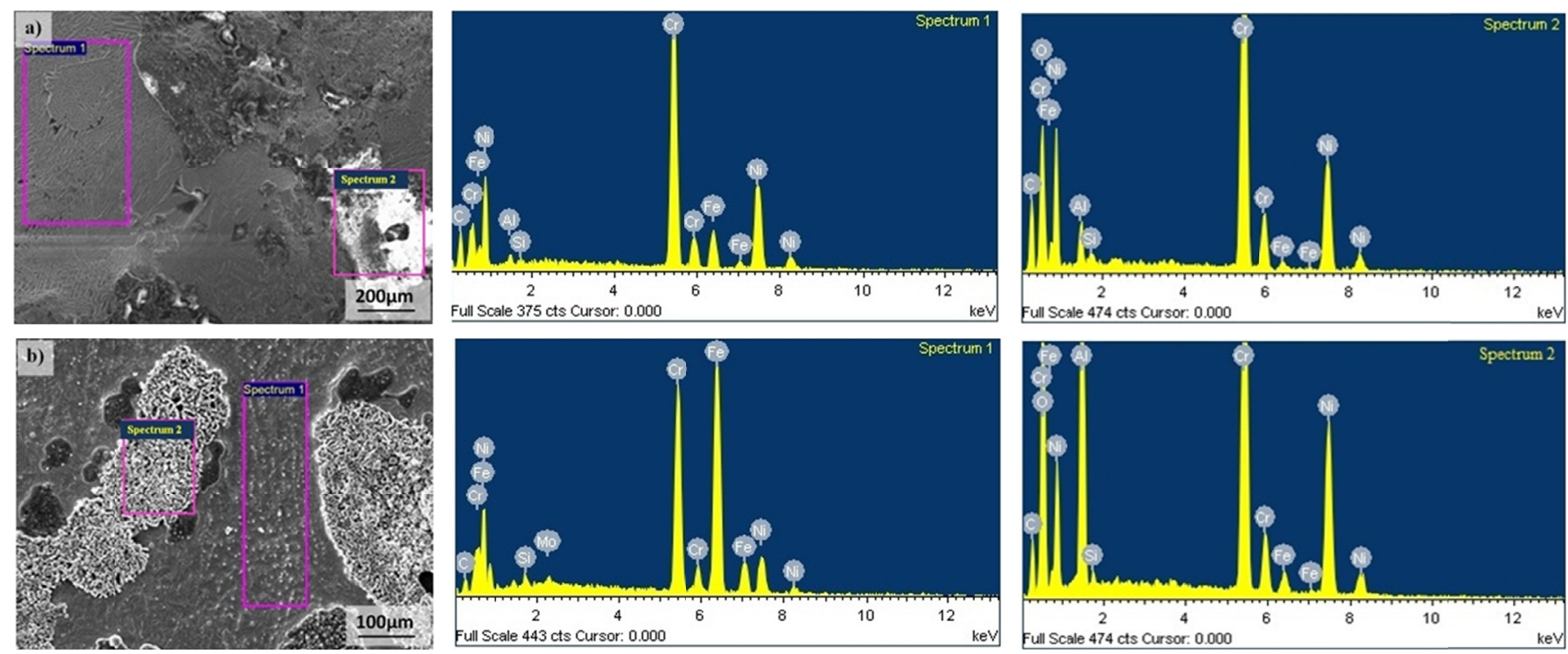

Fig. 10. Analysis of chemical composition of the surface in sintered duplex stainless steels (Spectrum 1 and Spectrum 2): a) after remelting at current intensity of $40 \mathrm{~A}, \mathrm{~b}$ ) after remelting at current intensity of $50 \mathrm{~A}$

alloying parameters was non-homogeneous in terms of chemical and phase compositions. The surface revealed oxide phases (Spectrum 2 in (Fig. 10)), likely to have been formed at the stage of solidification of the remelted mass.

Hardness measurements were used to evaluate mechanical properties. Table 6 presents hardness of the sintered duplex stainless steel, $\mathrm{Cr}_{3} \mathrm{C}_{2}$ coating and alloyed layer (50A). The results represent the mean of five measurements.

It is remarkable that addition of $\mathrm{Cr}_{3} \mathrm{C}_{2}$ ceramics to the surface layers during alloying leads to an single increase in hardness of layers obtained and an increase in homogeneity of the layer obtained across its thickness (Fig. 11).

Scratch test under constant load was used to evaluate the coefficient of friction and friction wear resistance. Table 7 presents the coefficient of friction for the materials obtained by the scratch method.
TABLE 6

Material hardness

\begin{tabular}{|c|c|}
\hline Materials & Hardness HV 0.1 \\
\hline Native material & $210.15 \pm 35.4$ \\
\hline $\mathbf{C r}_{\mathbf{3}} \mathbf{C}_{\mathbf{2}}$ coating & $252.70 \pm 9.9$ \\
\hline Surface alloying (50A) & $415.65 \pm 8.7$ \\
\hline
\end{tabular}

TABLE 7

Coefficient of friction

\begin{tabular}{|c|c|}
\hline Materials & $\begin{array}{c}\text { Coefficient of } \\
\text { friction }\end{array}$ \\
\hline Native material & 0.66 \\
\hline $\mathbf{C r}_{\mathbf{3}} \mathbf{C}_{2}$ coating & 0.59 \\
\hline Surface after alloying at current intensity of 35A & 0.48 \\
\hline Surface after alloying at current intensity of 40A & 0.44 \\
\hline Surface after alloying at current intensity of 50A & 0.25 \\
\hline
\end{tabular}




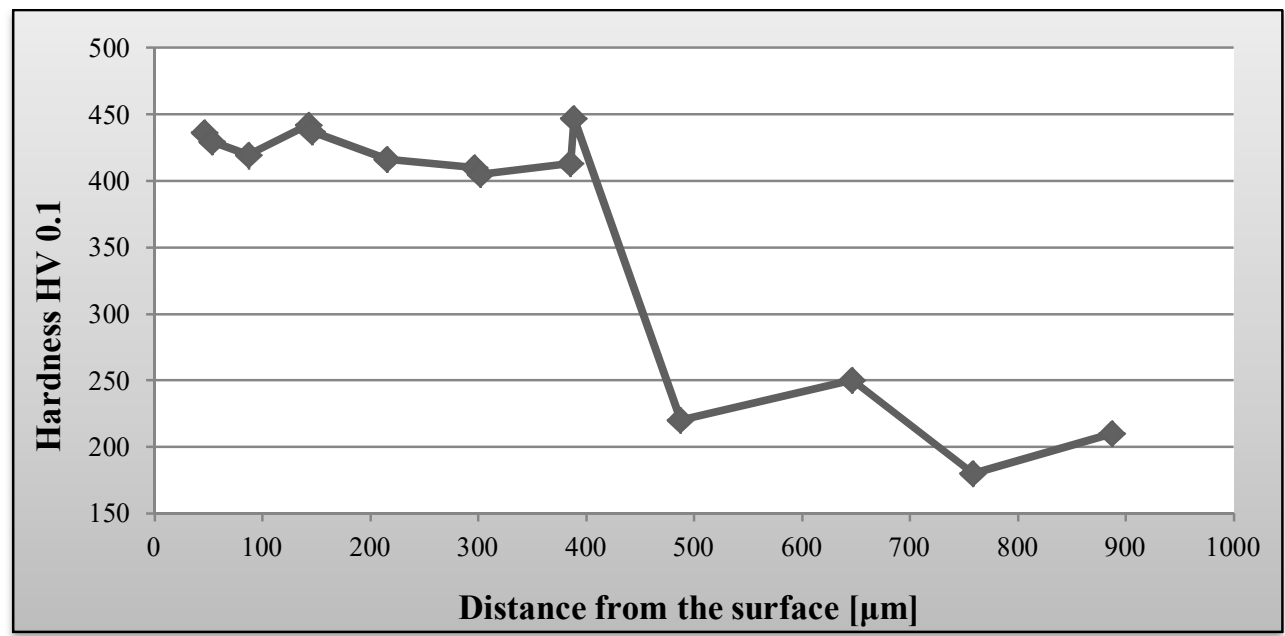

Fig. 11. Measurement of hardness of the alloyed surface layer vs. distance from the surface (50A)

Resistance to friction wear of sintered stainless steels is affected by several factors, e.g. microstructure, hardness, porosity and surface quality. The studies have demonstrated [17] that improved wear resistance in the group of austenitic-ferritic sinters is observed for steels with non-homogeneous microstructure and higher level of the hardness. Due to the alloying process the coefficient of friction in the layer was modified, which contributed to the improvement in tribological properties.

\section{Conclusions}

As demonstrated in the study, the modification of the surface layer material in sintered duplex steels proposed in the study leads to an increase in mechanical properties of sintered steels and their wear resistance, which should allow for a wider use of these modern materials. The results obtained in the study showed that the increase in current intensity causes a decrease in the coefficient of friction and increase in hardness, which consequently leads to the increased wear resistance. Wear resistance of corrosion-resistant sintered duplex steels depends on the microstructure and hardness of the surface layer.

\section{REFERENCES}

[1] E. Klar, P.K. Samal, Powder Metallurgy Stainless steels: Processing, Microstructures and Properties, 2007 ASM International, Materials Park, USA.

[2] J.C. Lippold, D.J. Kotecki, Welding Metallurgy and Weldability of Stainless Steels, 2005 John Wiley \& Sons.
[3] L. Sheppard, The Powder Metallurgy Industry Worldwide 20072012, 2007 Materials technology Publications, UK.

[4] M.M Asif, K.A. Shrikrishna, A.P. Sathiya, S. Goel, J. Manuf. Process. 18, 92-106 (2015).

[5] L.A. Dobrzański, Z. Brytan, M. Actis Grande, M. Rosso, JAMME 19 (1), 38-45 (2006).

[6] A. Dudek, A. Wrońska, L. Adamczyk, J. Solid State Electrochem. 18 (11), 2973-2981 (2014).

[7] A. Wrońska, A. Dudek, Arch. Civ. Mech. Eng. 14, 425-432 (2014).

[8] M. Campos, A. Bautista, D. Caceres, J. Abenojar, J.M. Torralba, J. Eur. Ceram. Soc. 23 (15), 2813-2819 (2003).

[9] F. Martin, C. Garcia, Y. Blanco, M.L. Rodriguez-Mendez, Mat. Sci. Eng. A-Struct. 642, 360-365 (2015).

[10] Z. Brytan, L.A. Dobrzański, M. Actis Grande, M. Rosso, JAMME 37 (2), 387-396 (2009).

[11] A.R. Annamalai, A. Upadhyaya, D.K. Agrawal, Can. Metall. Quart. 54 (2), 142-148 (2015).

[12] H. Jazi (Ed.), Advanced Plasma Spray Applications, 2012 InTech.

[13] L. Singh, V. Chawla, J.S. Grewal, J. Miner. Mater. Charact. Eng. 11 (3), 243-265 (2012).

[14] P. Peetsalu, S. Zimakov, J. Pirso, V. Mikli, R. Tarbe, P. Kulu, Proc. Estonian Acad. Sci. Eng. 12 (4), 435-444 (2006).

[15] H. Sarjas, P. Kulu, K. Juhani, M. Viljus, V. Matikainen, P. Vuoristo, P. Est. Acad. Sci. 65 (2), 101-106 (2016).

[16] G.C. Ji, C.J. Li, Y.Y. Wang, W.Y. Li, Surf. Coat. Tech. 200, 67496757 (2006).

[17] F. Martin, C. Garcia, Y. Blanco, M.L. Aparicio, Tribol. Int. 57, 76-85 (2013).

[18] Z. Brytan, M. Bonek, L.A. Dobrzański, JAMME 40 (1), 70-78 (2010).

[19] V. Muthupandi, P. Bala, S.K Srinivasan, S. Seshadri, V. Sundaresan, Mat. Sci. Eng. A-Struct. 358, 9-16 (2003). 